\title{
Surgical Repair of Fistula Between Right Coronary Artery and Main Pulmonary Artery: Case Report
}

\section{${ }^{1}$ Nazım Kankilic, ${ }^{1}$ Mehmet Salih Aydin, ${ }^{1}$ Mustafa Goz, ${ }^{2}$ Bisar Amac,}

${ }^{1}$ Medical School of Harran University, Department of Cardiovascular Surgery, Sanliurfa, Turkey

${ }^{2}$ Department of Perfusion, University of Health Science Mehmet Akif Inan Research and Training Hospital, Sanliurfa, Turkey

\section{Correspondence:}

Bişar AMAC

Department of Perfusion, University of Health Science Mehmet Akif Inan Research and Training Hospital, Sanliurfa, Turkey

e-mail: amacbisar@gmail.com

\section{Abstract}

Coronary artery fistulas (CAF) are uncommon cases. They may cause myocardial ischemia, arrhythmia, pulmonary hypertension, and heart failure. Treatment options are controversial and not clear. In this article we report surgical management of a case with right coronary artery fistula and concurrent coronary artery disease. A sixty-years-old male patient with stable angina symptoms admitted to our medical center. Coronary angiography examination showed a right coronary artery to pulmonary artery fistula and significant right coronary artery lesion located after the fistula's origin. CAF ligated epicardially and right coronary revascularization was performed. Coronary arterial fistulas cause important hemodynamic problems. Surgical and transcatheter interventional treatments are treatment options. Therefore indications for treatment are very important for these patients. The best therapeutic strategy (surgery or transcatheter intervention) is debatable. The surgical treatment is controversial especially for asymptomatic and small fistulas. However, there is consensus that large and symptomatic fistulas should be treated. Further research is necessary to deepen these observations.

Keywords: Coronary artery fistula, right coronary artery, pulmonary artery, coronary artery disease

Koroner arter fistülleri (KAF) nadir vakalardır. Miyokardiyal iskemi, aritmi, pulmoner hipertansiyon ve kalp yetmezliğine neden olabilirler. Tedavi seçenekleri tartıșmalı ve net değildir. Bu yazıda sağ koroner arter fistülü ve eșlik eden koroner arter hastalığı olan bir olgunun cerrahi tedavisini sunuyoruz. Altmış yaşında erkek hasta, stabil anjina semptomları ile tıp merkezimize başvurdu. Koroner anjiyografide, pulmoner artere doğru sağ koroner arter fistülü ve fistülün başlangıcından sonra yer alan belirgin sağ koroner arter lezyonu görüldü. KAF epikardiyal olarak kliplerle ligature edildi ve sağ koroner arter revaskülarizasyonu yapıldı. Koroner arter fistülleri önemli hemodinamik sorunlara neden olur. Cerrahi ve transkateter girişimsel işlemler tedavi seçenekleridir. Bu nedenle bu hastalar için tedavi endikasyonları çok önemlidir. En iyi tedavi stratejisi (cerrahi veya transkateter müdahale) hala net değildir. Özellikle asemptomatik ve küçük fistüllerde cerrahi tedavi tartıșmalıdır. Ancak büyük ve semptomatik fistüllerin tedavi edilmesi gerektiği konusunda fikir birliği vardır. Bu gözlemleri derinleştirmek için daha fazla araştırmaya ihtiyaç vardır.

Anahtar Kelimeler: Koroner arter fistül, Sağ koroner arter, Pulmoner arter, Koroner arter hastalığ1

Received 28.05.2021 Accepted 24.08.2021 Online published 24.08.2021 


\section{Introduction}

Coronary artery fistula (CAF) is a rare anomaly. According to the references, coronary anomalies have an incidence of $0.2-$ $1.2 \%$ in the general population $(1,2)$. Most of the coronary artery fistula is delivered to the right heart with a single fistula in $95 \%$ of cases and nearly all of them are small and asymptomatic (2). About $90 \%$ of CAFs drain to the right heart chambers/circulation (2). Large fistulas may cause heart failure, arrhythmias, pulmonary hypertension, endocarditis and angina pectoris (2,3). Surgical closure of CAF with sternotomy or thoracotomy has been described as a safe and effective mode of therapy (4). In this report, we present surgical treatment of a fistula from the right coronary artery (RCA) to the pulmonary artery.

\section{Case Presentation}

A sixty-year-old male patient was admitted to the cardiology out-patientclinic with stable angina and dyspnea. The electrocardiography (ECG) results showed negative $\mathrm{T}$ waves in the inferior leads. No ST segment change, pathological Q wave, branch block or rhythm disturbances were encountered. Echocardiography showed minimal mitral insufficiency and tricuspid insufficiency while both ventricular sizes were normal. The ejection fraction (EF) was not affected (EF: $\% 60$ ) and no sign of pulmonary hypertension or right ventricular overload were found. Coronary angiography was planned due to 2 packs per day for 20 years of cigarette smoking and a history of 10 years of type 2 diabetes mellitus disease. Coronary angiography showed a fistula arising from the right coronary artery and draining into the main pulmonary artery and a significant right coronary lesion located after the fistula's origin (Figure-1). Left system angiography was evaluated naturally. The treatment management was discussed in the cardiology and cardiovascular surgery council. It was concluded that the patient's complaints might be caused by both lesions and that it is difficult to differentiate the exact cause of patient's complaints. There is no definitive information in asymptomatic CAFs about surgical closureor percutaneous closure. This issue is still controversial. The presence of an untreated RCA and an unclosed CAF in the future may lead to ventricular dysfunction, pulmonary hypertension or stealing syndrome from the right coronary artery. For this reason, it was accepted that it would be beneficial to complete the treatment (RCA revascularization and closure of CAF) in order to avoid repetitive procedures and avoid aforementioned complications. Transcatheter treatment was considered to be first option (Stenting RCA (99\% occlusion) and reevaluation of the fistula afterwards). However, open surgery decision was taken considering the risk of early stent occlusion after percutaneous procedure $(5,6)$. Informed consent was obtained from the patient. Laboratory tests and pre-operative anesthesiology examination were assessed as normal before the operation. Under general anesthesia a median sternotomy was done. Aorta and two stage (unicaval) venous cannulations were performed. Cardiopulmonary bypass (CPB) was applied under normothermia. The fistula was easily identified in the epicardium after opening the pericardium. The fistulous communication was directly ligated epicardially by titanium clips (Ethicon Endo-Surgery 36 LIGACLIP $®$ LT200) (Figure-2). Further exploration of pulmonary artery was carried outto exclude the possibility of another existing fistula. No other fistula communication was observed and pulmonary artery was repaired and right coronary revascularization was performed. Follow up was uneventful, and the patient was discharged after one week post operatively. No problems occurred during the 2-year follow-up (2018-2020) after the operation. 


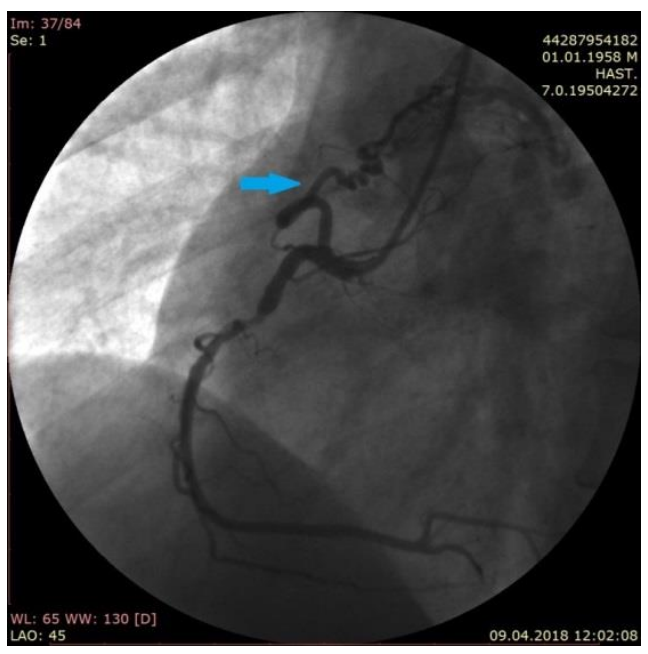

Figure 1. Right coronary artery fistula angiographic image

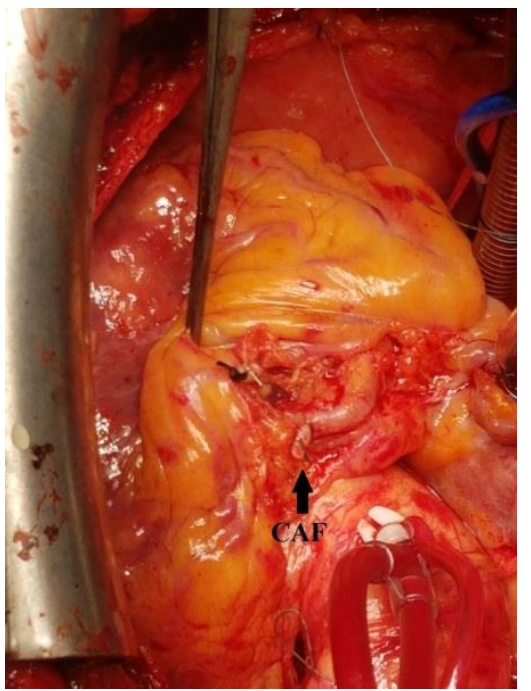

Figure 2. Surgical closure of the right coronary artery fistula

\section{Discussion}

Coronary artery fistulas have been extensively published in the English literature explaining the origin of coronary artery fistulas, their terminations and mode of treatments. It has been reported that coronary artery fistulas originating from the right coronary artery are encountered the most common with a rate of $52 \%(2,7,8)$. But, some authors referred that CAFs originate mostly from left anterior descending coronary artery (LAD) and left coronary system $(3,9)$.

Clinical manifestations of coronary artery fistulas (CAF) usually depend on the hemodynamic and anatomical features. Fistula size, drainage site and the origin of the CAF effects the symptoms and complications $(10,11)$. Pathophysiology includes flow changes and steal phenomenon resulting in oxygenation imbalance, myocardial ischemia or infarction (2). Fistulas draining into the left chambers cause increase in left ventricular volume and subsequently heart failure, whereas fistulas draining into the right heart or pulmonary circulation cause left-to-right shunt and subsequently right ventricular and pulmonary arterial volume overload (10). In addition, CAF's causes atherosclerosis because of coronary flow changes 2 . In 
particular, accompanying coronary artery disease further increases symptoms.

Indications for operation are not clear. It is controversial whether asymptomatic patients and small fistulas should be operated. However, we think that the large fistulas, symptomatic fistulas and patients with additional coronary pathologies should be treated. Delaying operation will lead to CAFinduced complications. This will increase the mortality and morbidity of surgical intervention (8).

Treatments include catheter-mediated stenting, embolization and surgical ligation (12). Transcatheter closure (occlusion devices, coils) may be preferred in patients without coronary artery disease, especially those with a single CAF. Vascular accesses are also important in the percutaneous repair of CAFs. In particular, radial access has been shown to reduce hemorrhagic events and mortality rates compared to transfemoral access (13).

Complications include transient arrhythmia, coronary artery spasm, fistula dissection, ST$\mathrm{T}$ wave change and coil embolization. Transcatheter and surgical applications show similar early efficacy on morbidity and mortality. Surgical ligation is one of the ideal treatments with low mortality rate $(1.4 \%)$ compared to other surgical techniques (14).

\section{REFERENCES}

1. Luo L, Kebede S, Wu S, Stouffer GA. Coronary artery fistulae. $\mathrm{Am} J$ Med Sci 2006; 332: 79-84 (Review).

2. Vaidya YP, Green GR.Coronary artery fistula. $J$ Card Surg. 2019 Sep 26.

3. Albeyoglu S, Aldag M, Ciloglu U, Sargin M, Oz TK, Kutlu H, et al..Coronary Arteriovenous Fistulas in Adult Patients: Surgical Management and Outcomes. Braz J Cardiovasc Surg. 2017; 32:15-21.

4. Hou B, Ma W, Zhang J, Du M, Sun H, Xu J, et al. Surgical management of left circumflex coronary artery fistula: a 25 -year single-center experience in 29 patients. Ann Thorac Surg. 2014; 97:530-6.

5. Kawamoto H, Tanaka K, Ruparelia N, Takagi K, Yabushita H, Watanabe Y, et al.Short-Term and LongTerm Outcomes After PolytetrafluoroethyleneCovered Stent Implantation for the Treatment of Coronary Perforation. Am J Cardiol. 2015 ;116:18226.
CPB is the most commonly used method in surgical ligation. However, it may not be used in lesions that are epicardial and easily visible $(2,3,10)$. Coronary artery fistula ligation can be performed safely in patients with additional coronary lesions, who have additional cardiac problems and large CAFs. However, postoperative bleeding, embolism, cardiac ischemia, and cardiopulmonary bypass complications are important aspects of the procedure.

According to our limited view and experience, the most important point to be determined in CAFs is identifying of treatment indications for coronary artery fistulas. CAFs should be evaluated according to the characteristics of the patients, presence of additional coronary lesions,anatomy of the coronary system and the localization of the fistulas. Large and symptomatic CAFs should be treated accordingly. Transcatheter intervention should be considered as the first choice in patients, but if surgical procedure is considered, early surgical procedure maintains the long-term functional capacity of these patients.

- $\quad$ Summary of this case report is presented at the 15th Congress of Turkish Cardiovascular Surgery Association, [PS241], 26-29 October 2018, Belek, Antalya.The full article has not been submitted/published elsewhere.
6. Hachinohe D, Latib A, Laricchia A, Iannopollo G, Demir OM, Ancona MB, et al.Long-term follow-up of covered stent implantation for various coronary artery diseases. Catheter CardiovascInterv. 2019;94:571-577 7. Huang YK, Lei MH, Lu MS, Tseng CN, Chang JP, Chu JJ.. Bilateral coronary-to-pulmonary artery fistulas. Ann ThoracSurg 2006; 82:1886-8.

8. Kamiya H, Yasuda T, Nagamine H, Sakakibara N, Nishida S, Kawasuji M, et al. Surgical treatment of congenital coronary artery fistulas: 27 years' experience and a review of the literature. J Card Surg 2002; 17:173-7.

9. Verdini D, Vargas D, Kuo A, Ghoshhajra B, Kim $\mathrm{P}$, Murillo $\mathrm{H}$, et al. Coronary-Pulmonary Artery Fistulas: A Systematic Review. J Thorac Imaging. 2016; 31:380-390.

10. Demirkilic U, Ozal E, Bingol H, Cingoz F, Gunay $\mathrm{C}$, Doganci S, et al. Surgical treatment of coronary artery fistulas: 15 years' experience. Asian Cardiovasc Thorac Ann. 2004 ; 12:133-8. 
11. Sohn J, Song JM, Jang JY, Sun BJ, Kim DH, Kang $\mathrm{DH}$, et al. Coronary artery fistula draining into the left ventricle. J Cardiovasc Ultrasound. 2014; 22:28-31.

12. Sharma UM, Aslam AF, Tak T. Diagnosis of Coronary Artery Fistulas: Clinical Aspect sand Brief Review of the Literature. Int J Angiol. 2013; 22:18992.

13. Cesaro A, Moscarella E, Gragnano F, Perrotta R, Diana V, Pariggiano I, et al.Transradial access versus transfemoral access: a comparison of outcomes and efficacy in reducing hemorrhagic events. Expert Rev CardiovascTher. $2019 ; 17: 435-47$.

14. Armsby LR, Keane JF, Sherwood MC, Forbess JM, Perry SB, Lock JE. Management of coronaryarteryfistulae. Patient selection and results of transcatheterclosure. J AmCollCardiol 2002;39.102632. 